\title{
Four new species of Cichlidogyrus (Monogenea: Ancyrocephalidae), gill parasites of Tilapia cabrae (Teleostei: Cichlidae), with discussion on relative length of haptoral sclerites
}

\author{
Antoine Pariselle ${ }^{1}$ and Louis Euzet $^{2}$ \\ ${ }^{1}$ Institut de Recherche pour le Développement /Groupement pour l'Aquaculture Méditerranéenne et Tropicale, B.P. 5095,34033 \\ Montpellier Cedex 1, France; \\ ${ }^{2}$ Station Méditerranéenne de l'Environnement Littoral, Université Montpellier II, 1 Quai de la Daurade, 34200 Sète, France
}

Key words: Monogenea, Ancyrocephalidae, Cichlidogyrus berradae, C. revesati, C. legendrei, C. lemoallei, Tilapia cabrae, Cichlidae, Africa

\begin{abstract}
Tilapia cabrae Boulenger, 1899, a cichlid fish from coastal lowlands of the Republic of Congo (Africa), was examined for gill parasites. Four new species of the Monogenea were found, all belonging to Cichlidogyrus (Ancyrocephalidae): C. berradae sp. n., C. revesati sp. n., C. legendrei sp. n., and C. lemoallei sp. n. A possible relationship between the relative size of haptoral sclerites (i.e., uncinuli compared to gripi) and microhabitat selection in the studied host-parasite model is discussed.
\end{abstract}

To date, only few gill monogeneans have been recorded or described from cichlid hosts in the Republic of Congo and neighbouring countries (Africa): Onchobdella aframae Paperna, 1968, O. voltensis Paperna, 1968, O. bopeleti Bilong Bilong et Euzet, 1995, Cichlidogyrus falcifer Dossou et Birgi, 1984, C. dageti Dossou et Birgi, 1984 and C. euzeti Dossou et Birgi, 1984 from Hemichromis fasciatus (Peters, 1857) in Cameroon; Cichlidogyrus flexicolpos Pariselle et Euzet, 1995 and C. microscutus Pariselle et Euzet, 1996 from Tilapia guineensis (Bleeker, 1862) and Scutogyrus chikhii Pariselle et Euzet, 1995 from Oreochromis mossambicus (Peters, 1852) in the Republic of Congo. The latter host species has probably been introduced to the Republic of Congo for aquaculture purpose and escaped to the wild, where it was sampled. Considering the high species richness and the oioxenous specificity of cichlid gill parasites (Pariselle 1996), we may expect to find numerous new species of the Monogenea when studying endemic cichlids from this region. As predicted, the study of Tilapia cabrae Boulenger, 1899 (Teleostei, Cichlidae), distributed in lowlands from Southern Equatorial Guinea to Angola, revealed the presence of four new species belonging to Cichlidogyrus Paperna, 1960 (Monogenea, Ancyrocephalidae), which are described below.

\section{MATERIALS AND METHODS}

Fish were captured in various rivers and lakes of coastal area of the Republic of Congo using gill or cast nets. They were dissected on site immediately after capture by separating the gill arches. The left arches were frozen in liquid nitrogen, until examination. After thawing, the parasites were detached from the gills using a strong water current and transferred individually with a needle directly into a drop of ammonium picrate-glycerine mixture (Malmberg 1957). The preparation was then covered with a cover slip and sealed with Glyceel (Gurr, BDH Chemicals). From these preparations, drawings were made of the sclerotised pieces of the haptor and of the copulatory complex, using a drawing tube. All measurements, in $\mu \mathrm{m}$, are given as: mean \pm standard deviation (minimummaximum), as proposed by Gussev (1962) (Fig. 1). To verify the specific identity of host fishes, the carcasses were numbered, fixed and preserved in formalin and later determined by G.G. Teugels (MRAC, Tervuren, Belgium). The scientific names of fishes are given according to the check-list published by Daget et al. (1991). The method of numbering the uncinuli (marginal hooklets) is that adopted at ICOPA IV (Euzet and Prost 1981). Terminology is that proposed for the Dactylo-gyridea by Pariselle and Euzet (1995). In this order, the ontogeny of uncinuli is characterised by the development of secondary shafts attached to the primary ones, except for uncinuli pair II, associated with ventral gripi (anchor), which keep their larval size (Fig. 2). The development the secondary shaft is variable according to pair number and parasite species.

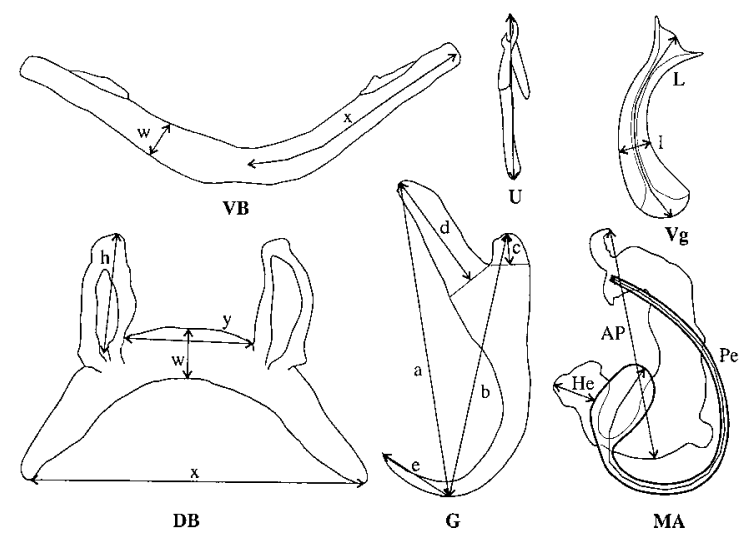

Fig. 1. Measurements used in this study. AP - accessory piece; DB - dorsal transverse bar; $\mathrm{G}$ - gripus; $\mathrm{He}$ - heel; MA - male apparatus; Pe - penis; U - uncinulus; VB - ventral transverse bar; $\mathrm{Vg}$ - vagina. 


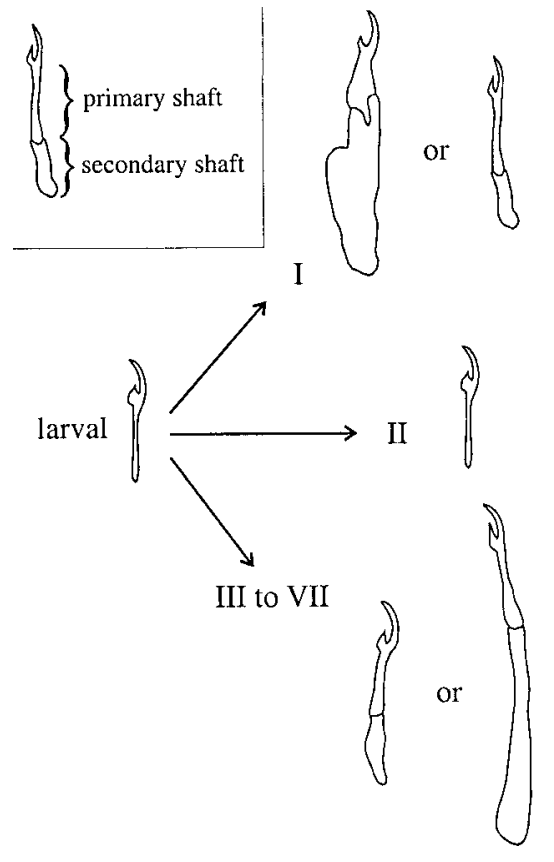

Fig. 2. Ontogenetic development of uncinuli in Cichlidogyrus (Dactylogyridea).

\section{RESULTS}

Cichlidogyrus berradae sp. $n$.

Fig. 3

Description. Adult: $569 \pm 72$ (381-678) long, $87 \pm$ 13.8 (65-119) wide at level of penis. Pharynx: $32 \pm 2.7$ (28-37) wide. Dorsal gripus with guard four times longer than shaft, arched blade bent at middle: $\mathrm{a}=44 \pm$ $1.8(40-48), \mathrm{b}=33 \pm 1.3(28-36), \mathrm{c}=4 \pm 1(1-6), \mathrm{d}=$ $16 \pm 0.8(14-18), \mathrm{e}=16 \pm 0.8(14-18)$. Dorsal transverse bar: $\mathrm{x}=35 \pm 2(32-40), \mathrm{w}=7 \pm 0.6(6-9), \mathrm{h}=15$ $\pm 1.2(13-18), y=13 \pm 1.9(10-19)$. Ventral gripus with short shaft, short guard, blade regularly arched: $a=39 \pm$ $1.4(35-42), b=37 \pm 1.4(33-40), c=4 \pm 0.9(2-6), d=$ $10 \pm 1.1(7-13), \mathrm{e}=16 \pm 1.1(13-18)$. V-shaped ventral transverse bar: $\mathrm{x}=40 \pm 1.7(37-45), \mathrm{w}=5 \pm 0.6(4-6)$. Uncinuli I = $26 \pm 1$ (24-28) long; II, associated with ventral gripi $=11 \pm 0.5(10-13)$ long; III $=19 \pm 0.8$ (20-23) long, $\mathrm{IV}=21 \pm 0.7$ (20-23) long, $\mathrm{V}=23 \pm 0.7$ (21-24) long, VI $=21 \pm 0.7$ (20-23) long, VII $=19 \pm$ 0.9 (17-21) long. Male copulatory complex with short, slightly arched penis with long thin heel: $\mathrm{Pe}=36 \pm 1.3$ (33-37), $\mathrm{He}=8 \pm 0.6$ (5-9). Accessory piece, linked to base of penis, ending in long, thin hook: Ap $=38 \pm 4.4$ (28-47). Non-sclerotised vagina.

T y p e h o s t: Tilapia cabrae Boulenger, 1899 (Perciformes, Cichlidae).

T y p e 1 o c a 1 i t y : Lake Cayo (Kabinda), $5^{\circ} 3^{\prime} \mathrm{S}, 12^{\circ} 5^{\prime} \mathrm{E}$, 06/1993.

$\mathrm{O} t \mathrm{~h}$ e $\mathrm{r}$ h o s t: Tilapia guineensis (Bleeker, 1862), Lake Loufoualéba, near Pointe Noire (Republic of Congo), $4^{\circ} 53^{\prime} \mathrm{S}, 11^{\circ} 57^{\prime} \mathrm{E}, 06 / 1993$.

Site of infection: Gills.
M a t e ri a 1 s t u d i e d: 30 individuals.

$\mathrm{D}$ e $\mathrm{p}$ o s i t i o $\mathrm{n}$ of $\mathrm{t}$ y $\mathrm{p}$ e $\mathrm{s}$ : Holotype at the Muséum National d'Histoire Naturelle (Paris): MNHN 538 HF Tk63. Paratypes at the Muséum National d'Histoire Naturelle (Paris): MNHN 538 HF Tk64; the British Museum (Natural History) (London): BMNH 1997.1.29.1; the Musée Royal d'Afrique Centrale (Tervuren): MRAC 37 409; the Institute of Parasitology, Academy of Sciences of the Czech Republic (České Budějovice): M-385.

$\mathrm{E} \mathrm{t} y \mathrm{~mol} \mathrm{og} \mathrm{y}$ : The name is proposed in honour of Professor Ouafae Berrada-Rkhami, a fish parasitologist from the Mohamed V University of Rabat (Morocco).

Remarks. Cichlidogyrus berradae belongs to the group of Cichlidogyrus species with large uncinuli I (secondary shaft longer than total length of larval uncinuli), short uncinuli pairs III to VII (secondary shaft shorter than total length of larval uncinuli), a short penis $(<50 \mu \mathrm{m})$ without a swollen portion and a nonsclerotised vagina ${ }^{1}$. This group includes $C$. dionchus Paperna, 1968; C. halinus Paperna, 1969 (syn. C. erectus Dossou, 1982; see remarks in Pariselle and Euzet 1996); C. digitatus Dossou, 1982; C. quaestio Douëllou, 1993; C. yanni Pariselle et Euzet, 1996 and C. nuniezi Pariselle et Euzet, 1998. Cichlidogyrus berradae is distinguishable from all these species by a single long and thin hook-shaped ending of the accessory piece. Cichlidogyrus digitatus has two digitations at the end of its accessory piece; one is a long, thin hook but the presence of the second short digitation allows differentiation of these two species; $C$. yanni has only one digitation, but it is a short, rounded hook (see Pariselle and Euzet 1996).

Cichlidogyrus reversati $\mathrm{sp}$. $\mathrm{n}$.

Fig. 4

Description. Adult: $713 \pm 106$ (545-1,011) long, $109 \pm 31.3(59-178)$ wide at level of penis. Pharynx: 32 \pm 3 (25-38) wide. Dorsal gripus with very long guard five times longer than shaft ${ }^{2}$, arched blade bent at the distal half: $\mathrm{a}=59 \pm 1.9(53-63), \mathrm{b}=42 \pm 1.8(36-45)$, $\mathrm{c}=4 \pm 1.8(2-14), \mathrm{d}=21 \pm 1.7(17-28), \mathrm{e}=14 \pm 1.1$ (11-16). Dorsal transverse bar with characteristic auricles: $\mathrm{x}=46 \pm 2.3(42-51), \mathrm{w}=11 \pm 1.4(9-15), \mathrm{h}$ $=18 \pm 2.2(14-24), y=15 \pm 2.4(12-24)$. Ventral gripus with short shaft, short guard (see remark above), blade regularly arched: $\mathrm{a}=44 \pm 2(40-49), \mathrm{b}=44 \pm 1.6(40$ $46), c=3 \pm 1.3(1-9), d=11 \pm 1.5(6-16), e=16 \pm 1.3$ (13-19). V-shaped ventral transverse bar: $\mathrm{x}=45 \pm 3.2$ (37-50), $\mathrm{w}=9 \pm 1.4(6-13)$. Uncinuli $\mathrm{I}=25 \pm 1.5(22-$ 28) long, II $=12 \pm 0.8$ (9-14) long, III $=18 \pm 0.8$ (1721) long, $\mathrm{IV}=22 \pm 0.9$ (20-25) long, $\mathrm{V}=24 \pm 1.3(20$ 27) long, $\mathrm{VI}=21 \pm 0.8$ (20-23) long, VII $=19 \pm 0.9$ (15-20) long. Short, large penis with folded widemouthed end, poorly developed heel: $\mathrm{Pe}=33 \pm 1.4$ (31$36), \mathrm{He}=3 \pm 0.4(2-4)$. Short C-shaped accessory piece ending in a hook, Ap $=20 \pm 1.5$ (17-23). Nonsclerotised vagina.

T y p e h o s t: Tilapia cabrae Boulenger, 1899 (Perciformes, Cichlidae).

${ }^{1}$ See discussion in Dossou (1982) and determination key in Pariselle (1996).

${ }^{2}$ Shafts and guards are sometimes connected by one to four anastomoses, which explains the wide range of measurements for these two parts of the dorsal gripus. 


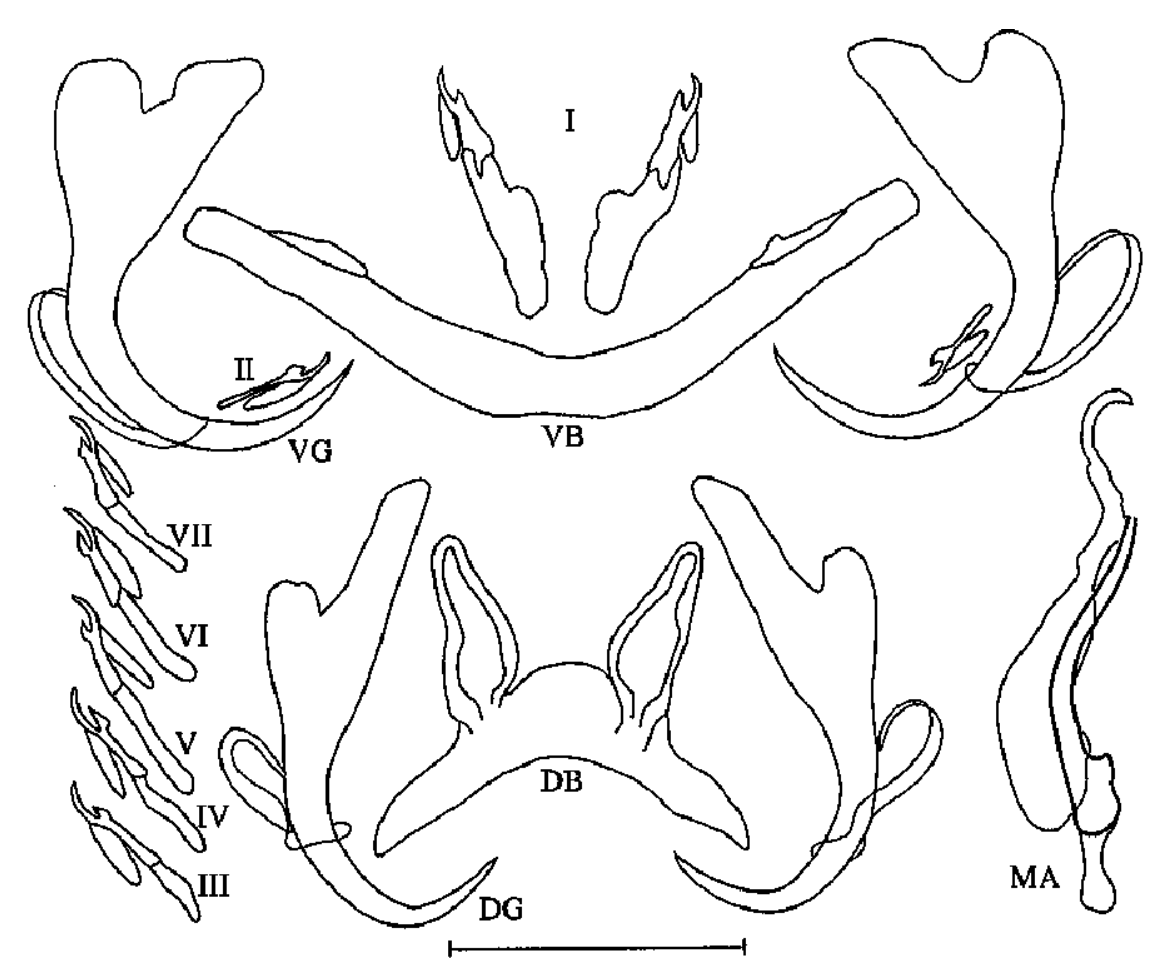

Fig. 3. Cichlidogyrus berradae sp. n. DB - dorsal transverse bar; DG - dorsal gripus; MA - male apparatus; VB - ventral transverse bar; VG - ventral gripus; I-VII - marginal uncinuli. Scale bar $=30 \mu \mathrm{m}$.

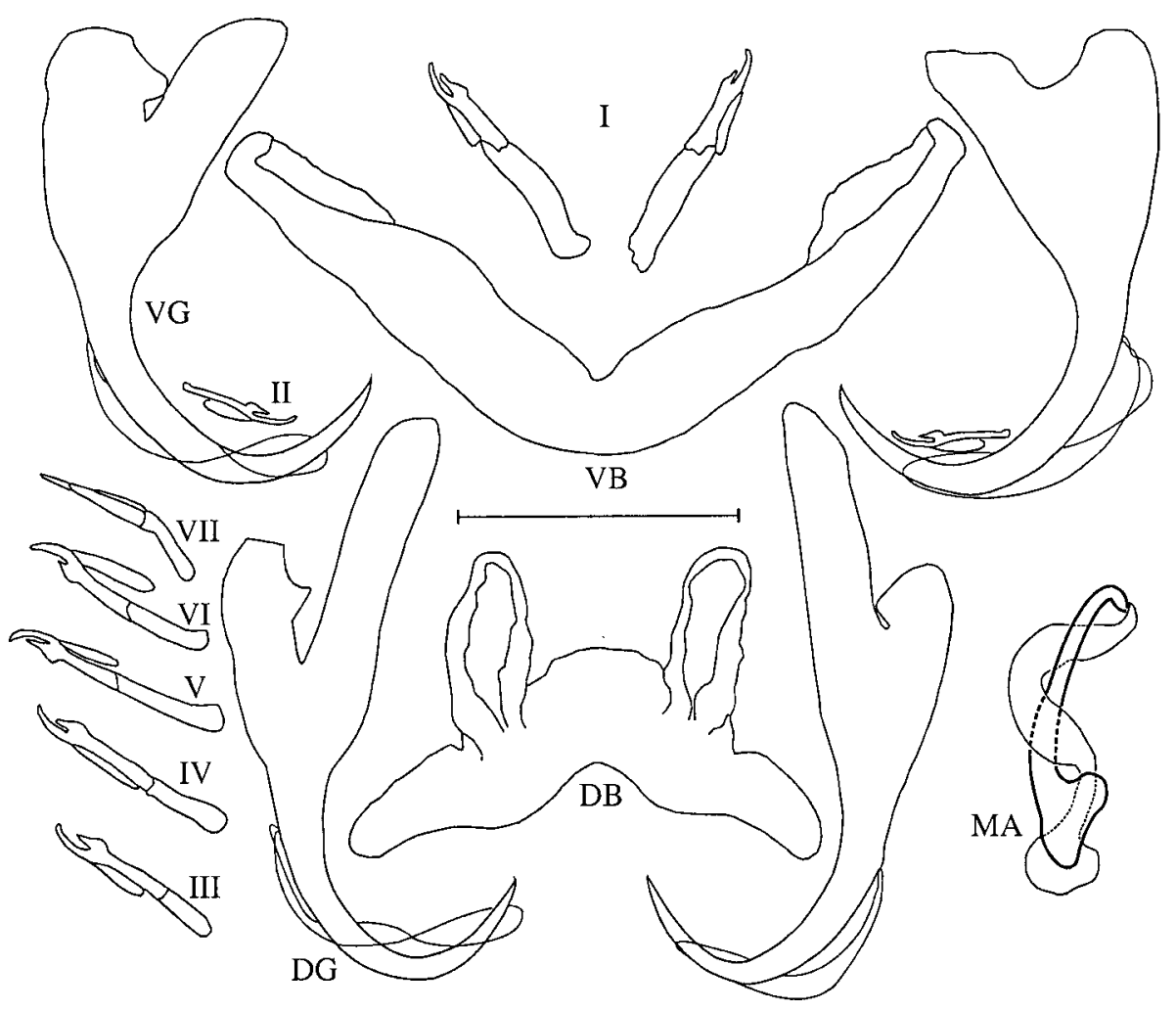

Fig. 4. Cichlidogyrus reversati sp. n. DB - dorsal transverse bar; DG - dorsal gripus; MA - male apparatus; VB - ventral transverse bar; VG - ventral gripus; I-VII - marginal uncinuli. Scale bar $=30 \mu \mathrm{m}$. 
T y p e 1 o c a 1 i t y : Mouth of the Bas Kouilou River (Republic of Congo), $4^{\circ} 28^{\prime} \mathrm{S}, 11^{\circ} 43^{\prime} \mathrm{E}, 06 / 93$.

Site of infection: Gills.

Materia 1 st udied:30 individuals.

De position of t y p e s: Holotype at the Muséum National d'Histoire Naturelle (Paris): MNHN 541 HF Tk69. Paratypes at the Muséum National d'Histoire Naturelle (Paris): MNHN 541 HF Tk70; the British Museum (Natural History) (London): BMNH 1997.1.29.4; the Musée Royal d'Afrique Centrale (Tervuren): MRAC 37 402; the Institute of Parasitology, Academy of Sciences of the Czech Republic (České Budějovice): M-386.

E $\mathrm{t} \mathrm{y} \mathrm{m} \mathrm{o} 1$ o g y : The name is proposed in honour of Drs. France and Georges Reversat, who kindly helped us in the collection of material from Congo.

Remarks. Cichlidogyrus reversati belongs to the same morphological group of Cichlidogyrus species as $C$. berradae. In this group, Cichlidogyrus reversati is easily distinguishable from $C$. berradae, $C$. digitatus, $C$. dionchus, $C$. nuniezi and $C$. quaestio by the shape of the accessory piece of the penis (C-shaped and ending in a large hook in C. reversati); from $C$. halinus ${ }^{3}$ by the size of the penis (31-36 vs. 25-30 $\mu \mathrm{m}$ ), of the accessory piece $(17-23 v s .30-32 \mu \mathrm{m})$ and the length of the uncinuli I (22-28 vs. 30-32 $\mu \mathrm{m})$; from $C$. yanni by the shape and length of the heel $(3 v s .6 \mu \mathrm{m})$ and by the absence of a folded and wide-mouthed end of the penis in C. yanni.

\section{Cichlidogyrus legendrei sp. $\mathrm{n}$.}

Fig. 5

Description. Adult: $658 \pm 73$ (532-838) long, $111 \pm$ 15 (85-147) wide at level of penis. Pharynx: $37 \pm 2.4$ (32-41) wide. Dorsal gripus with guard two times longer than the shaft, arched blade bent at distal third: $\mathrm{a}=29 \pm 1.1(26-31), \mathrm{b}=24 \pm 0.7(22-25), \mathrm{c}=6 \pm 0.6$ $(5-8), \mathrm{d}=12 \pm 1(10-14), \mathrm{e}=10 \pm 0.8(7-12)$. Dorsal transverse bar, arched, with two auricles on its convex face: $\mathrm{x}=47 \pm 4.8$ (39-59), $\mathrm{w}=7 \pm 0.7(6-8), \mathrm{h}=16 \pm$ $1.2(13-19), y=18 \pm 1.7(15-21)$. Ventral gripus similar to dorsal, slightly heavier: $\mathrm{a}=35 \pm 0.8(33-36)$, $\mathrm{b}=30 \pm 0.7(29-31), \mathrm{c}=7 \pm 0.7(5-8), \mathrm{d}=13 \pm 1.2$ $(10-15), \mathrm{e}=11 \pm 0.8(10-13)$. V-shaped ventral transverse bar: $\mathrm{x}=44 \pm 2.4(39-50), \mathrm{w}=5 \pm 0.6(5-6)$. Short uncinuli $\mathrm{I}=19 \pm 0.8$ (17-20) long; II $=13 \pm 0.8$ (11-14) long, III $=38 \pm 1.3$ (36-41) long, IV $=43 \pm 1.2$ (39-47) long, $\mathrm{V}=44 \pm 1.2$ (41-47) long, $\mathrm{VI}=41 \pm 1.3$ (38-44) long, VII $=38 \pm 1.4(35-41)$ long. Sinuous penis with ovoid basal bulb and heel: $\mathrm{Pe}=71 \pm 2.8$ (65-76), He $=5 \pm 0.3$ (4-6). Large S-shaped accessory piece with a hook perpendicular to the ending: $A p=45$ \pm 2.7 (38-52). Slightly arched, thick-walled vagina: $\mathrm{V}=$ $26 \pm 2.7(21-31), v=5 \pm 0.6(4-6)$.

T y p e h o s t: Tilapia cabrae Boulenger, 1899 (Perciformes, Cichlidae).

T y p e 1 o c a 1 i t y : Lake Cayo (Kabinda), $5^{\circ} 3$ 'S, $12^{\circ} 5^{\prime} \mathrm{E}$, 06/1993.

Site of infection: Gills.

Mate ria 1 s t udied : 18 individuals.
D e p o s itio n of t y p e s: Holotype at the Muséum National d'Histoire Naturelle (Paris): MNHN 539 HF Tk65. Paratypes at the Muséum National d'Histoire Naturelle (Paris): MNHN 539 HF Tk66; the British Museum (Natural History) (London): BMNH 1997.1.29.2; the Musée Royal d'Afrique Centrale (Tervuren): MRAC 37 400; the Institute of Parasitology, Academy of Sciences of the Czech Republic (České Budějovice): M-387.

$\mathrm{E} \mathrm{t}$ y $\mathrm{m} \mathrm{o} \mathrm{log} \mathrm{g}$ : The name is proposed in honour of Dr. Marc Legendre, a fish reproduction biologist from IRD (ex-ORSTOM).

Remarks. Cichlidogyrus legendrei belongs to the group of Cichlidogyrus species with small uncinuli I (secondary shaft shorter than total length of larval uncinuli), long uncinuli III to VII (secondary shaft longer than total length of larval uncinuli), no auxiliary plate associated to the male apparatus, and a large and tubular vagina. This group includes Cichlidogyrus tiberianus Paperna, 1960; C. halli Paperna, 1960; C. anthemocolpos Dossou, 1982; C. ergensi Dossou, 1982; C. ouedraogoi Pariselle et Euzet, 1996; C. kouassii N'Douba, Thys van den Audenaerde et Pariselle, 1997; C. bonhommei Pariselle et Euzet, 1998; C. hemi Pariselle et Euzet, 1998. The new species is mainly distinguishable from $C$. halli (very large) by the shape and dimensions of the penis; by the shape and dimensions of the vagina from $C$. bonhommei and $C$. tiberianus (looped), from C. hemi (short, straight and ringed), from $C$. kouassii (S-shaped); and by the shape and dimensions of the accessory piece, from $C$. anthemocolpos (two points at the distal end) and from C. ergensi and C. ouedraogoi (smaller and thinner).

\section{Cichlidogyrus lemoallei $\mathrm{sp} . \mathrm{n}$.}

Fig. 6

Description. Adult: $605 \pm 94$ (421-718) long, $119 \pm$ 19 (92-156) wide at level of penis. Pharynx: $32 \pm 4.4$ (25-40) wide. Dorsal gripus with shaft two times longer than guard, arched blade bent at distal third: $\mathrm{a}=30 \pm 1$ $(28-32), b=24 \pm 1.5(22-27), c=6 \pm 0.9(4-7), d=13$ \pm 1.4 (11-18), e $=10 \pm 0.9(8-12)$. Dorsal transverse bar, arched, with two auricles on its convex face: $\mathrm{x}=35$ \pm 3.5 (29-41), $\mathrm{h}=16 \pm 1.6(13-19), \mathrm{w}=6 \pm 0.9$ (5-8), $\mathrm{y}=14 \pm 1.5(12-17)$. Ventral gripus similar to dorsal but slightly heavier: $\mathrm{a}=35 \pm 1.3(32-37), \mathrm{b}=29 \pm 1.5$ (26-33), c = 6 $\pm 1.2(4-8), \mathrm{d}=14 \pm 1(12-16), \mathrm{e}=11 \pm$ 0.9 (9-13). V-shaped ventral transverse bar: $\mathrm{x}=36 \pm$ 1.8 (32-39), $\mathrm{w}=5 \pm 0.9$ (4-7). Short uncinuli $\mathrm{I}=17 \pm$ 0.7 (16-19) long; II, associated with ventral gripus $=12$ \pm 0.7 (11-14) long; III $=35 \pm 2.1$ (31-38) long, $\mathrm{IV}=40$ \pm 1.7 (37-43) long, $\mathrm{V}=41 \pm 1.4$ (39-45) long, $\mathrm{VI}=38$ \pm 1.3 (36-41) long, VII $=36 \pm 1.5$ (33-38) long. Male copulatory complex composed of a G-shaped tubular penis: $\mathrm{Pe}=69 \pm 2.6(63-74)$, a thin heel: $\mathrm{He}=3 \pm 0.8$ (2-5) and a C-shaped accessory piece, attached to heel, folded at right angle at distal quarter, ending in a terminal hook: $\mathrm{Ap}=31 \pm 3.4$ (24-37). Thin, long, slightly sinuous vagina: $\mathrm{V}=50 \pm 4(41-58), \mathrm{v}=2 \pm 0.4$ $(2-3)$. 


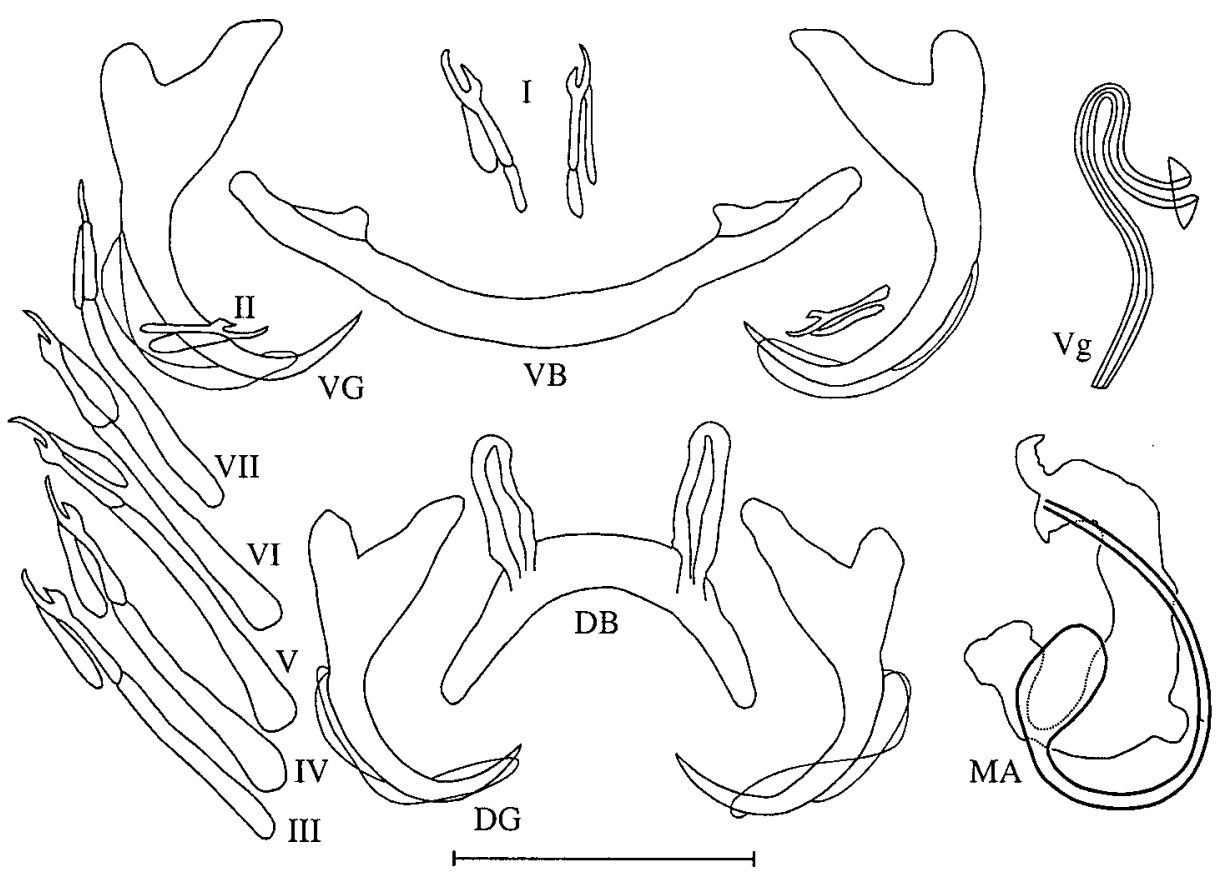

Fig. 5. Cichlidogyrus legendrei sp. n. DB - dorsal transverse bar; DG - dorsal gripus; MA - male apparatus; VB - ventral transverse bar; VG - ventral gripus; Vg - vagina; I-VII - marginal uncinuli. Scale bar $=30 \mu \mathrm{m}$.

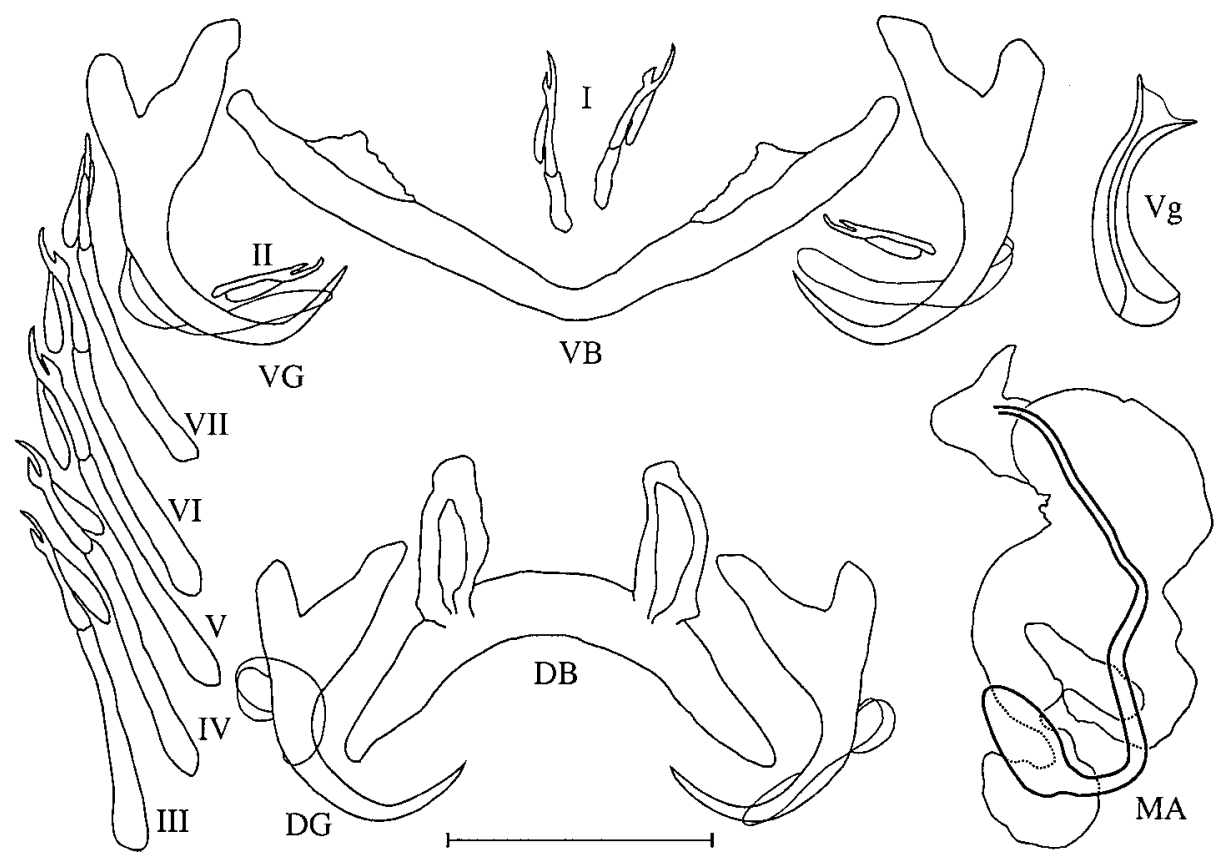

Fig. 6. Cichlidogyrus lemoallei sp. n. DB - dorsal transverse bar; DG - dorsal gripus; MA - male apparatus; VB - ventral transverse bar; VG - ventral gripus; Vg - vagina; I-VII - marginal uncinuli. Scale bar $=30 \mu \mathrm{m}$. 
T y p e h o s t: Tilapia cabrae Boulenger, 1899 (Perciformes, Cichlidae).

$\mathrm{T}$ y p e 1 o c a 1 i t y : Mouth of the Bas Kouilou River (Republic of Congo), $4^{\circ} 28^{\prime} \mathrm{S}, 11^{\circ} 43^{\prime} \mathrm{E}, 06 / 93$.

$\mathrm{O}$ t h e r 1 o c a 1 i t i e s : Loukoula River (Republic of Congo) (material provided by Dr. Guy Teugels, MRAC, Tervuren) and in Lake Cayo (Kabinda), $5^{\circ} 3^{\prime} \mathrm{S}, 12^{\circ} 5^{\prime} \mathrm{E}$, 06/1993.

Site of infection: Gills.

Material st udied: 15 individuals.

De p o s ition of type s: Holotype at the Muséum National d'Histoire Naturelle (Paris): MNHN 540 HF Tk67. Paratypes at the Muséum National d'Histoire Naturelle (Paris): MNHN 540 HF Tk68; the British Museum (Natural History) (London): BMNH 1997.1.29.3; the Musée Royal d'Afrique Centrale (Tervuren): MRAC 37 401; the Institute of Parasitology, Academy of Sciences of the Czech Republic (České Budějovice): M-388.

$\mathrm{E} \mathrm{t} \mathrm{y} \mathrm{mol}$ o g y : The name is proposed in honour of Dr. Jacques Lemoalle, a hydrobiologist from IRD (exORSTOM).

Remarks. Cichlidogyrus lemoallei belongs to the group of Cichlidogyrus species with small uncinuli I (secondary shaft shorter than total length of larval uncinuli), long uncinuli III to VII (secondary shaft longer than total length of larval uncinuli), no auxiliary plate associated to the male apparatus and a long and narrow vagina. This group includes Cichlidogyrus testificatus Dossou, 1982 and C. flexicolpos Pariselle et Euzet, 1995. The new species is easily distinguishable from C. flexicolpos by the length of the penis $(85 \mathrm{vs} .69$ $\mu \mathrm{m})$ and from $C$. testificatus by the shape of the accessory piece (T-shaped $v s$. C-shaped).

\section{DISCUSSION}

In spite of its Central African restricted distribution, Tilapia cabrae shows a fauna of Cichlidogyrus spp. highly homogeneous with West African studied cichlid hosts. This is not surprising if we consider that the evolution of monogenean gill parasites is directed by that of their hosts (see Pariselle et al. 2003). There is no doubt that the examination of other cichlid species from this area will allow us to describe numerous new species of Cichlidogyrus.

An examination of the newly described species shows that the length of uncinuli (i.e., the development of secondary shaft, see above) and that of gripi are in inverse proportion (e.g., C. berradae dorsal gripus "a" $=44 \mu \mathrm{m}$ and uncinulus III $=19 \mu \mathrm{m} v s$. "a" $=29 \mu \mathrm{m}$ and $\mathrm{III}=38 \mu \mathrm{m}$ for $C$. legendrei). Is this tendency valid for all Cichlidogyrus species? The examination of the graph built after the length of dorsal gripus $v s$. that of uncinulus III for the 55 species (data after Pariselle 1996) described from tilapiine hosts (i.e., genera Tilapia, Sarotherodon and Oreochromis; see Trewavas 1983) does not clearly confirm the tendency (Fig. 7). On the other hand, and knowing that within the "short uncinuli

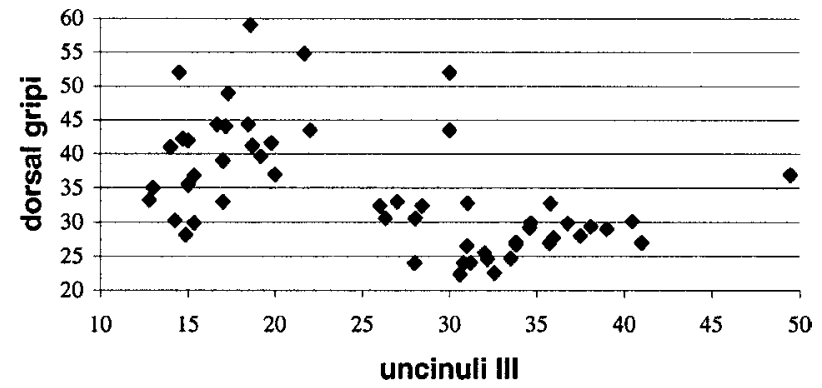

Fig. 7. Length of uncinuli III $v s$. length of dorsal gripi (in $\mu \mathrm{m}$ ) in 55 species of Cichlidogyrus from West African tilapiine hosts. (Based on data from Pariselle 1996.)

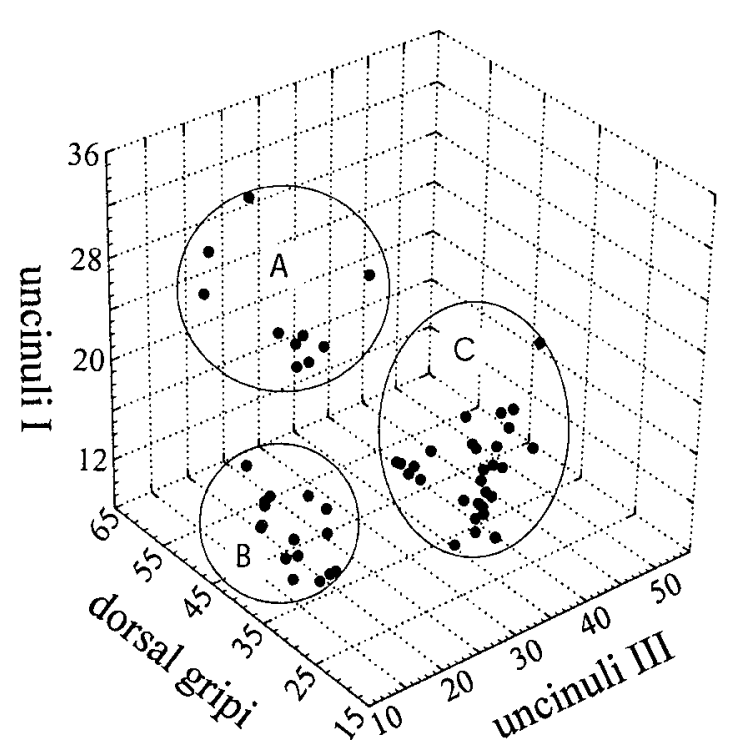

Fig. 8. Length of uncinuli III $v s$. length of dorsal gripi $v s$. length of uncinuli I (in $\mu \mathrm{m}$ ) in 55 species of Cichlidogyrus from West African tilapiine hosts. (Based on data from Pariselle 1996.)

III to VII" group of species (i.e., uncinuli shorter than $25 \mu \mathrm{m}$ ) there are both long and short uncinuli I (i.e., shorter than $20 \mu \mathrm{m}$ ), the three-dimensional graph (length of dorsal gripi $v s$. uncinuli III vs. uncinuli I) shows distinctly the presence of three groups (Fig. 8), A: long uncinuli I, short uncinuli III and long gripi; B: short uncinuli I, short uncinuli III, and medium gripi; and C: short uncinuli I, long uncinuli III and small gripi.

Two hypotheses may be speculated: these different morphologies have been patterned by the adaptation to specific microhabitats on the gills (i.e., adaptation resulting from interspecific competition), or patterned only by the ontogeny (i.e., limited by the energy available to build the hard parts of the haptor).

No answer could actually be given, but microhabitat segregation between monogenean species on the gills is well documented (e.g., for Monopisthocotylea by Lambert and Maillard 1974, Wootten 1974, Cloutman 
1975, Fernando and Hanek 1976, Hanek and Fernando 1978, Sanfilippo 1978, Silan 1984, Ramasamy et al. 1985, Adams 1986, Janovy et al. 1991, Koskivaara et al. 1992, etc.). Further studies have to be done to confirm this segregation in the present tilapiine-
Cichlidogyrus model (see Bilong Bilong et al. 1999 for Hemichromis fasciatus) to highlight the link between the morphology of haptoral sclerites and specific microhabitat, and finally to conclude about the determining factor in monogenean site selection.

\section{REFERENCES}

ADAMS A.M. 1986: The parasite community on the gills of Fundulus kansae (Garman) from the South Platte River, Nebraska (USA). Acta Parasitol. Pol. 31: 47-54.

BILONG BILONG C.F., Le POMMELET E., SILAN P. 1999: The gills of Hemichromis fasciatus Peters, 1858 (Teleostei, Cichlidae), a biotope for ectoparasites: structure, heterogeneity and growth models. Ecologie 30: $125-130$.

CLOUTMAN D.G. 1975: Parasite community structure of largemouth bass, warmouth, and bluegill in Lake Fort Smith, Arkansas. Trans. Am. Fish. Soc. 104: 277-283.

DAGET J., GOSSE J.-P., TEUGELS G.G., THYS van den AUDENAERDE D.F.E. 1991: Check-list of the Freshwater Fishes of Africa. Vol. IV. ISNB (Bruxelles), MRAC (Tervuren) \& ORSTOM (Paris), 740 pp.

DOSSOU C. 1982: Parasites de poissons d'eau douce du Bénin III. Espèces nouvelles du genre Cichlidogyrus (Monogenea) parasites de Cichlidae. Bull. Inst. Fondam. Afr. Noire 44: 295-322.

EUZET L., PROST M. 1981: Report of the meeting on Monogenea: problems of systematic, biology and ecology. In: W. Slusarski (Ed.), Review of Advances in Parasitology. P.W.N., Polish Scientific Publishers, Warsaw, pp. 10031004.

FERNANDO C.H., HANEK G. 1976: Gills. In: C.R. Kennedy (Ed.), Ecological Aspects of Parasitology. North-Holland Publishing Company, Amsterdam, pp. 209-226.

GUSSEV A.V. 1962: In: E. Bychovskaya-Pavlovskaya et al. (Ed.), Key to Parasites of Freshwater Fish of the USSR. Publ. House of Academy of Sciences of the USSR, Moscow - Leningrad, 919 pp. (Translated from Russian by IPST, Ser. No. 1136, Jerusalem, 1964).

HANEK G., FERNANDO C.H. 1978: Spatial distribution of gill parasites of Lepomis gibbosus (L.) and Amblopites rupestris (Raf.). Can. J. Zool. 56: 1235-1240.

JANOVY J. Jr., MacDOWELL M.A., FERDIG M.T. 1991: The niche of Salsuginus thalkeni, a gill parasite of Fundulus zebrinus. J. Parasitol. 77: 697-702.

KOSKIVAARA M., VALTONEN E.T., VUORI K.M. 1992: Microhabitat distribution and coexistence of Dactylogyrus species (Monogenea) on the gills of roach. Parasitology 104: 273-281.

LAMBERT A., MAILLARD C. 1974: Répartition branchiale de deux monogènes: Diplectanum aequans (Wagener, 1857) Diesing, 1858 et Diplectanum laubieri Lambert et Maillard, 1974 (Monogenea, Monopisthocotylea) parasites simultanés de Dicentrarchus labrax (Téléostéen). Ann. Parasitol. Hum. Comp. 50: 691-699.
MALMBERG G. 1957: On the occurrence of Gyrodactylus on Swedish fishes. (In Swedish, with description of species and a summary in English.) Skrifter utgivna av Sodra Sveriges Fiskeriforening, (1956), pp. 19-76.

PARISELLE A. 1996: Diversité, spéciation et évolution des Monogènes branchiaux de Cichlidae en Afrique de l'Ouest. PhD Thesis, University of Perpignan, France, 199 pp.

PARISELLE A., EUZET L. 1995: Gill parasites of the genus Cichlidogyrus Paperna, 1960 (Monogenea, Ancyrocephalidae) from Tilapia guineensis (Bleeker, 1862), with descriptions of six new species. Syst. Parasitol. 30: 187198.

PARISELlE A., EUZET L. 1996: Cichlidogyrus Paperna, 1960 (Monogenea, Ancyrocephalidae): gill parasites from West African Cichlidae of the subgenus Coptodon Regan, 1920 (Pisces), with descriptions of six new species. Syst. Parasitol. 34: 109-124.

PARISELLE A., MORAND S., DEVENEY M., POUYAUD L. 2003: Parasite species richness of closely related hosts: historical scenario and "genetic" hypothesis. In: C. Combes and J. Jourdane (Eds.), Taxonomie, Écologie et Évolution des Métazoaires Parasites - Taxonomy, Ecology and Evolution of Metazoan Parasites. (Livre hommage à Louis Euzet). Vol. 2. PUP, Perpignan, France, pp. 147-166.

RAMASAMY P., RAMALINGAM K., HANNA R.E.B., HALTON D.W. 1985: Microhabitats of gill parasites (Monogenea and Copepoda) of teleosts (Scomberoides spp.). Int. J. Parasitol. 15: 385-397.

SANFILIPPO D. 1978: Microhabitats des Monogènes Dactylogyroidea parasites branchiaux de Téléostéens Mugilidae et Sparidae. PhD Thesis, Université des Sciences et Techniques du Languedoc, Montpellier, 148 pp.

SILAN P. 1984: Biologie comparée des populations de Diplectanum aequans et D. lauberi, monogènes branchiaux de Dicentrarchus labrax. PhD Thesis, Université des Sciences et Techniques du Languedoc, Montpellier, 275 pp.

TREWAVAS E. 1983: Tilapiine Fishes of the Genera Sarotherodon, Oreochromis and Danakilia. British Museum (Natural History), London, Publication No. 878, $583 \mathrm{pp}$.

WOOTTEN R. 1974: The spatial distribution of Dactylogyrus amphibathrium on the gills of ruffe Gymnocephalus cernua and its relation to the relative amounts of water passing over the parts of the gills. J. Helminthol. 48: 167174. 